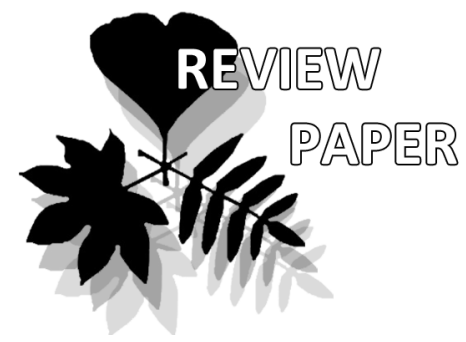

\title{
The Early Cretaceous Flora of Razdol'naya River Basin (Primorye Region, the Russian Far East)
}

\author{
Eugenia V. Bugdaeva*, Elena B. Volynets, Valentina S. Markevich
}

Eugenia V. Bugdaeva*

e-mail: bugdaeva@biosoil.ru

Elena B. Volynets

e-mail:volynets@biosoil.ru

Valentina S. Markevich

e-mail: markevich@biosoil.ru

Institute of Biology and Soil Science FEB RAS, Vladivostok 690022 Russia

* corresponding author

Manuscript received: 10.10 .2015

Review completed: 22.10 .2015

Accepted for publication: 25.10.2015

Published online: 28.10 .2015

\begin{abstract}
A B S T R A C T
Study of the Early Cretaceous (the Barremian-Albian) flora of Primorye region was begun by V.A. Krassilov more than 60 years ago. It was a significant contribution to knowledge of the Cretaceous floras of Asia. The most diverse and abundant flora occurs in the Razdolnaya River Basin of the Primorye region. We continue to research this fossil plant assemblage using light and scanning electron microscopy.
\end{abstract}

K e y w o r d s : fossil flora, Early Cretaceous, Razdol'naya River Basin, Primorye region

\section{P E 3 Ю M E}

Бугдаева Е.В., Волынец Е.Б., Маркевич В.С. Раннемемовая фмора Раздольненского бассейна (Приморье, российский Аальний Восток). Изучение раннемеловой (баррем-альбской) флоры РазАольненского бассейна Приморья было начато В.А. Красиловым более 60 лет назац Это был значительный вклаА в познание меловых флор Азии. Наиболее разнообразной и обильной является флора Раздольненского бассейна. Мы продолжаем исследовать ее с помощью светового и сканирующего электронного микроскопов..

К $\boldsymbol{\Lambda}$ ю ч е в ы е с $\boldsymbol{\Lambda}$ о в а : ископаемая флора, ранний мел, Раздольненский бассейн, Приморье
Only a small number of taxa in the Early Cretaceous flora of the Primorye region (the Russian Far East) has received a full-fledged up-to-date treatment. Thus a lot of problems remain unsolved, and current solutions are no more than tentative. Perceptions of the flora have changed gradually, from it being a "Indian-European Flora" to a "Siberian-Canadian Flora". Major evolutionary changes took place in the ferns, conifers and early angiosperms in the Aptian and Albian stages. The Early Cretaceous vegetation of the Primorye region was remarkably conservative, but it changed rapidly during the Albian, related to intensive volcanism, intensification of tectonic processes, climatic deterioration, and extinctions at higher trophic levels. The paleogeographical significance of the Early Cretaceous plants here is still not fully appreciated, and the importance of the fossil record is often obscured by prevaling dogmatic tectonic interpretations.

The Early Cretaceous flora of the Primorye region, one of the richest in the world, shows an important stage of the florogenesis of Asia. The uniqueness of the flora was caused by its position at the boundary between the IndoEuropean and Siberian-Canadian regions.

The first information about finds of these plant remains appeared at the end of the 19th century, but their systematic study was begun by Afrikan Nikolaevich Kryshtofovich at the beginning of the 20th century (Kryshtofovich 1910, 1916, 1919, 1921, 1923). He has revealed two different floras: an older Mesozoic one was named as the Mongugay flora, and a younger Mesozoic one, the Nikan flora. Consequently discoveries of angiosperms allowed Kryshtofovich to define more precisely the age of the latter assemblage, as the Early Cretaceous (Kryshtofovich 1928, 1929). Later palaeobotanical studies were continued by Prynada $(1937,1939,1941)$, Shtempel $(1924,1926,1960)$, Vakhrameev (1959), and Samylina (1961), with identifications of new taxa of these Early Cretaceous plants.

In the early 1960s, in the Primorye a talented paleobotanist, stratigrapher and geologist, Valentin Abramovich Krassilov, began his work. Already his first publications showed that an outstanding researcher had appeared in science. In 1965, he defended his thesis on "The Early Cretaceous flora of Southern Primorye and its importance for the stratigraphy", and two years later his monograph was published, the provisions of which have not lost their significance today. This work manifested an amount of studied material and a high level of its comprehension that was revolutionary for those years. One of the first in the field, Krassilov applied the epidermal-cuticular methods which allowed him to reveal new features of the morphology of fossil plant leaves and reproductive organs.

Krassilov devoted a lot of time to research on the flora and stratigraphy of the Razdol'naya River coal basin, located in the southwestern Primorye region (Fig. 1). The sequence of deposits is represented there by the Nikan Group 


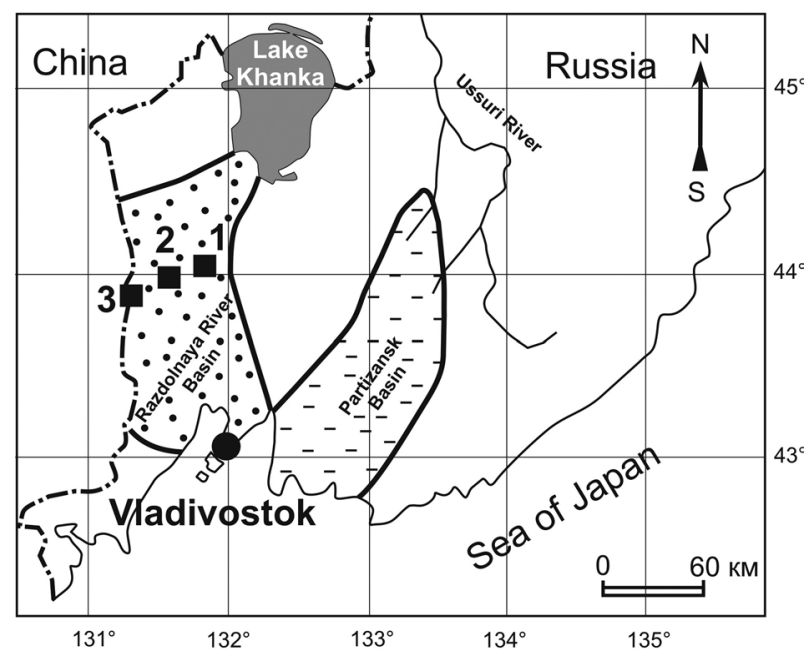

Figure 1. Study localities. 1 - Lipovtsy coalfield, 2 - Ilyichevka coalfield, 3 - Konstantinovskoe coalfield

(Barremian-Albian) and Korkino Group (Albian-Cenomanian). At the suggestion of Krassilov (1965), the first was divided into the Ussuri (Barremian), Lipovtsy (Aptian) and Galenky (Albian) formations. Of greatest interest is the Lipovtsy Formation because of its industrial significance in its coal-bearing deposits (Krassilov 1967).

In the 1960s, Krassilov first studied the extremely diverse (141 species) Early Cretaceous flora of the Razdolnaya River Basin. He described 60 new species, reconstructed the patterns of the vegetation and climate change at that time, and drew a correlation with coeval floras of China, Korea, Japan, and Western Canada (Krassilov 1964a, b, 1965a, b, c, d, 1967). The main conclusions of Krassilov on the flora and stratigraphy of the basin have not lost their relevance today.

Palaeobotanical research on the Razdolnaya River Basin since the 1980s has been continued by Volynets, who, together with geologists of the Primorye Survey of "Primorgeologiya", collected plant remains extensively. As a result of her study, the taxonomic composition of the floras of the Ussuri, Lipovtsy and Galenky formations and the Korkino Group has been significantly augmented, and the geological age of these stratigraphic units defined more precisely (Volynets 2005, 2006). Additionally, a new species of Miroviaceae was described by Nosova (2001).

In contrast to the palaeobotanical studies, palynological work on the Razdolnaya River Basin began only in the 1960 s, and was related to the definition of the age of the Cretaceous strata for the geological mapping of the region (Bolkhovitina \& Kotova 1963, Verbitskaya 1965, Shugaevskaya 1962, 1966, 1977). The narrower scope of the application of palynology was broadened by Markevich, who, in addition to the development of palynostratigraphy (palynological zonation), first considered some theoretical issues, such as the problem of the synchronicity of bioevents during the Cretaceous Period, the division of palynozones in East Asia, tracing the appearance events and the morphological evolution of the pollen of flowering plants, the recognition of the rates of evolution of the Cretaceous palynoflora, and hence the palynofloral differentiation in accordance with the climatic and tectonic zones (Markevich 1994, 1995).
In recent years, a detailed study on the plants giving rise to coals of the Lipovtsy, Ilyichevka and Konstantinovka coalfields of the Razdolnaya Basin was begun.

\section{The Lipovtsy Coalfield}

At the beginning of the last century Kryshtofovich worked here. He drew particular attention to "... coal, compact, hard, brownish-black, matte, heavy, filled, or rather more weight consisting of fine needles of resin material penetrating it in all directions, brilliant in the section..." (Kryshtofovich 1928). To this material he allocated a special class of liptobiolith coals - rhabdopissite (from the

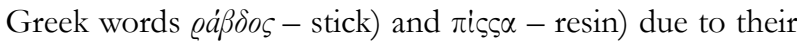
composition like gum sticks. Also, Kryshtofovich suggested that these sticks "... no other than the resin or gum filling of ducts of trees, conifers or rather - cycadophytes, that probably bennettitaleans..." (ibid). Subsequently, with respect to rhabdopissite-forming plants, palaeobotanists and coal geologists followed the views of Kryshtofovich.

Chemical research on rhabdopissite resin sticks revealed that their parent matter was tannal and resinol resins, different in composition from the resins of conifers (Ammosov et al. 1973). Therefore, these could not have been the producers of the Lipovtsy's liptobioliths.

According to palynological data, the opinion was expressed that the source materials for coals of the Razdolnaya Basin were the remains of conifers, ferns, horsetails, club mosses, cycadaleans, bennettitaleans, ginkgoaleans, and mosses (Verbitskaya et al. 1965). A situation when almost all groups of plants were involved in the formation of coal gives rise to doubt. It should be noted that the composition of palynospectra reflects most the averaged composition of the vegetation in the whole of the drainage basin. Along with this, a complicating factor is the different degree of productivity of anemo-zoophilous plants, as well as the ways that palynomorphs were transported to their place of burial. These factors should be taken into account in the reconstructions of the marsh plant communities, representatives of which formed the coal.

After more than a hundred years there remains the problem that the plants which gave rise to rhabdopissites have not been revealed. The fact of the matter is that paleobotanists actually have not investigated such phytogenic rocks as coal. Usually they have collected plant remains from clastic strata (mudstone, siltstone, and sandstone), underlying and overlying the coal seams. It was to the plants found in these interlayers that the coal-forming role was ascribed, whereas terrigenous sedimentation takes place in a completely different environments; the sedimentary material transported from the highlands to the lowlands carried plant fragments. Consequently, the plant taphocoenoses have a mixed type, as in their composition both marsh plants and slope plant communities are represented.

Based on the fact that coal is phytogenic rock, it was decided to use its bulk maceration. To obtain disperse cuticles the coals dissolved in concentrated nitric acid, washed with distilled water, then exposed to $10 \%$ alkali $(\mathrm{KOH})$ and also washed. Isolated cuticles were mounted into preservative medium of permanent preparations. 

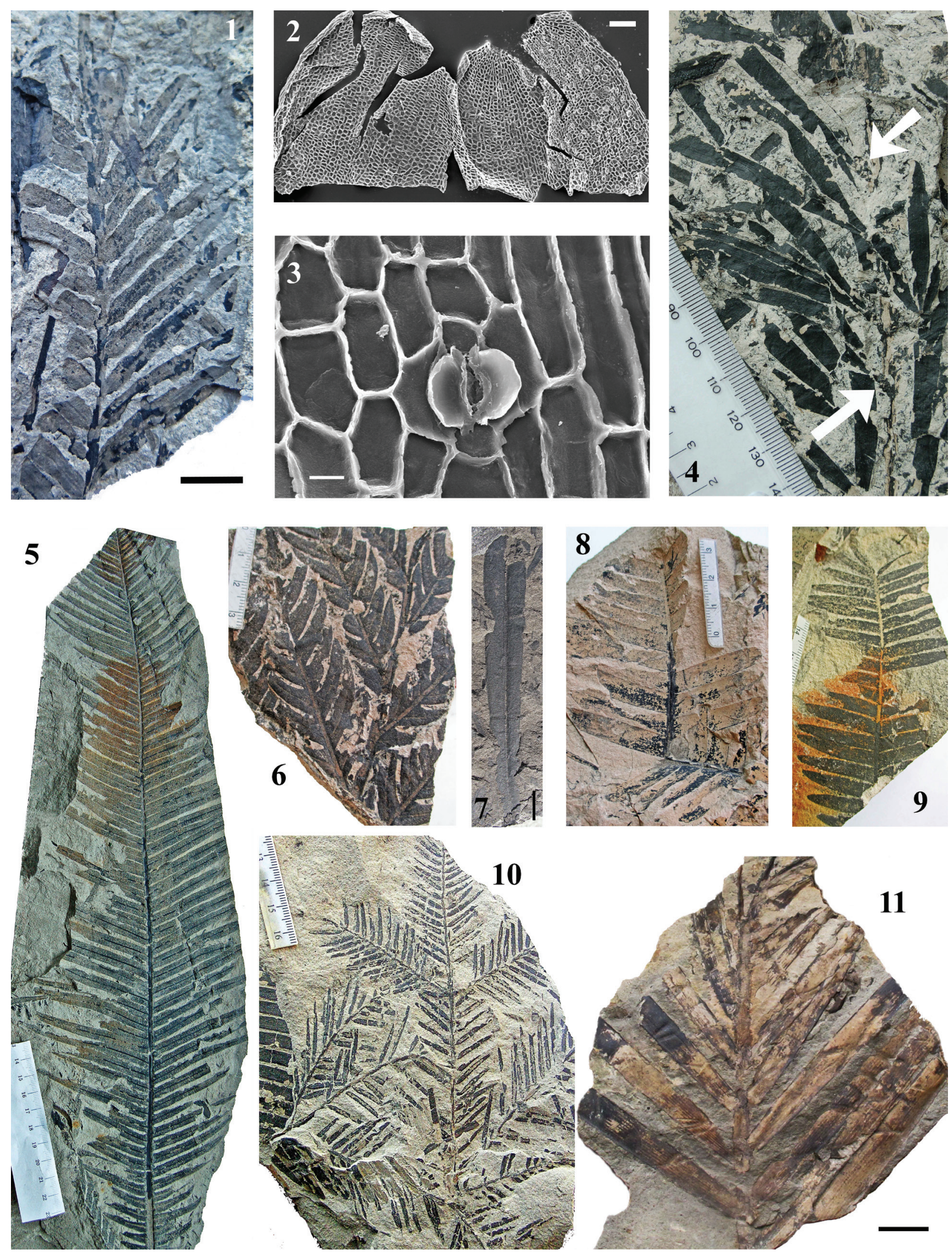

Plate 1 Fig. 1. Mirovia orientalis (Nosova) Nosova, Lipovtsy Coalfield, Lipovtsy Formation, scale bar $1 \mathrm{~cm}$; Fig. 2. Mirovia orientalis, Lipovtsy Coalfield, Lipovtsy Formation, lower and upper cuticle of upper part of leaf, scale bar $200 \mu \mathrm{m}$; Fig. 3. Mirovia orientalis, Lipovtsy Coal Field, Lipovtsy Formation, lower cuticle of leaf, stoma, inner view, scale bar $20 \mu \mathrm{m}$; Fig. 4. Psendotorellia krassilovii Bugdaeva, Lipovtsy Coalfield, Lipovtsy Formation, white arrows indicate short shoots; Fig. 5. Nathorstia pectinata (Goeppert) Krassilov, Lipovtsy Coalfield, Lipovtsy Formation; Fig. 6. Cladophlebis frigida (Heer) Seward, Lipovtsy Coal Field, Lipovtsy Formation; Fig. 7. Nilssoniopteris rhitidorachis (Kryshtofovich) Krassilov, Lipovtsy Coalfield, Lipovtsy Formation; scale bar $1 \mathrm{~cm}$; Fig. 8. Pterophyllum sutschanense Prynada, Lipovtsy Coalfield, Lipovtsy Formation; Fig. 9. Pterophyllhm aff. burejense Prynada, Lipovtsy Coalfield, Lipovtsy Formation; Fig. 10. Torreya nicanica Krassilov, Lipovtsy Coalfield, Lipovtsy Formation; Fig. 11. Zamiophyllum ivanovii (Kryshtofovich et Prynada) Krassilov, Lipovtsy Coalfield, Lipovtsy Formation, scale bar $1 \mathrm{~cm}$ 
However, this method has a significant shortcoming. Fern fronds' fine phytoleimma do not usually stand the maceration, in which case the information about this group of plants is lost. But palynological data can fill this gap, as spores have thick exine, resistant to chemicals.

Thus, using data on plant macrofossils, spores and pollen, it is possible to define the composition of the coalforming plants and restore the structure of swamp communities.

It was revealed during the maceration of rhabdopissite from thick productive coal seam "Rabochiy" in Lipovtsy coal mine that the constituent part of coal of is predominantly (almost $100 \%$ ) the remains of leaves of Mirovia orientalis (Nosova) Nosova (Plate 1, Figs. 1-3) relating to Miroviaceae. In the formation of humic coals of this coalfield a ginkgoaleans played significant role (Pseudotorellia krassilovii, Plate 1, Fig. 4). The ferns (such as Cyatheaceae and Gleicheniaceae) also were a part of coal-forming plants.

Krassilov (1967) has collected abundant plant remains from the productive "Rabochiy" coal seam - in all 31 taxa. According to him, the most common plants are ferns Nathorstia pectinata (Plate 1, Fig. 5), Cladophlebis frigida (Plate 1, Fig. 6), cycadophytes Nilssoniopteris rithidorachis (Plate 1, Fig. 7), Pterophyllum sutschanense (Plate 1, Fig. 8), P. aff. burejense (Plate 1, Fig. 9), Ctenis yokoyamae, C. latiloba, conifers Podocarpus harrisii. We revealed deposits dominated by Torreya nicanica (Plate 1, Fig. 10) and Zamiophyllum ivanovii (Plate 1, Fig. 11).

The palynospectrum of rhabdopissite from the "Rabochiy" coal seam is characterized by the dominance of bisaccate pollen of such as taxa of the Pinaceae and Podocarpaceae, whereas that relatable to the Taxodiaceae played a lesser role. Ginkgocycadophytus sp. and Eucommiidites troedsonii Potonié are of little importance; and the taxonomic diversity of ferns is low. They are represented by mainly by taxa relatable to the Cyatheaceae and Dicksoniaceae and, to a lesser degree, close to the Gleicheniaceae. Representatives of taxa relatable to the Schizaeaceae, Osmundaceae, and Polypodiaceae constitute a small part of the pollen spectrum.

In the deposits we have found in the burials in situ the matoniaceous fern Nathorstia pectinata, and the cyatheaceous fern Alsophilites nipponensis (Oishi) Krassil. which produced, respectively, large numbers of spores Leiotriletes and Cyathidites, which predominate in the palynospectra.

Based on the study of lithofacies, it has been deduced that the "Rabochiy" coal seam was formed in a period of the maximum peneplanation of the relief, in a vast alluvial valley with lakes, river channels and floodplains under hot and humid climatic conditions (Sharudo 1972). Also, according to this author, the rhabdopissites of the Lipovtsy coalfield accumulated in the littoral zone of a lake.

The coals are enriched by light resin bodies, with extremely comminuted cuticle of leaves, which may indicate a rather long-range transport from the place of growth to the burial site. Almost monospecific burials of miroviaceous leaves are known (Manum et al. 2000, Kirichkova 1985, Gordenko 2004, 2007), which is evidence of the dominant role of these plants in the lowland vegetation. There is no doubt that they have made a significant contribution to the formation of resinous coal, although it is not yet entirely clear what their role was in the formation of the liptobioliths of the Razdolnaya River Basin.

As mentioned above, the palynospectra of the "Rabochiy" coal seam are, besides bisaccate pollen, dominated by spores of Cyatheaceae, Dicksoniaceae, and Gleicheniaceae. Ferns with thin cuticles cannot withstand the chemical maceration of coals, and are absent in residues. But, based on the dominance of these spores in the palynospectra and finds in the coal seam's roof of rosettes and fronds of Nathorstia pectinata (Matoniaceae) and Alsophilites nipponensis (Cyatheaceae), we can assume they played a dominant role in the peat formation along the shores of Lake Lipovtsy.

According to our data, the representatives of the Cyatheaceae were the predominant component of palynospectra in the Late Jurassic coals of the Bureya Basin and Early Cretaceous coals of Transbaikalia, the Amur River region and the Primorye region. Beginning with the Berriasian, the Gleicheniaceae intruded into swamp plant communities (Bugdaeva \& Markevich 2007); in the Aptian they became the dominant plants. Ginkgoaleans, especially Pseudotorellia and Sphenobaiera, also supplied material for coal formation (Krassilov 1972, Bugdaeva 1995, 2010). During the Mesozoic, Pseudotorellia was a dominant form in wetland plant communities in the Eurasia (Bugdaeva 1999). As elsewhere, the coal-forming plants in the Aptian of Lipovtsy coalfield remained the cyatheaceous and gleicheniaceous ferns, and Psendotorellia, but the Miroviaceae played the main role.

\section{Ilyichevka Coalfield (Porechensky quarry)}

For the first time, we have conducted a palaeobotanical study of the recently opened Porechensky quarry, in which the coal seams of the Ilyichevka coalfield crop out.

In the Porechensky quarry the section, alternating of light yellowish-gray sandstones and dark grey silty mudstones occur, and several interbedded seams of coal have been studied. The thickness of the coal seams varies from 0.3 to $7 \mathrm{~m}$.

After maceration of coal from all coal beds, the dispersed cuticles were obtained. As a result, we have been able to reveal the taxonomic composition of the plants composing the coal. The residue from the lower thick coal seam consisting of rhabdopissite $(7-9 \mathrm{~m})$ is dominated by dispersed cuticles described by Krassilov as representatives of Araucariaceae (Araucariodendron cf. angustifolium Krassil. and $A$. beterophyllum Krassil.). Rare cuticles of Pseudotorellia sp. also occur. Apparently, some of the coal-forming plants were also gleicheniaceous and cyatheaceous ferns, whose spores are prevalent in palynospectrum in this bed. The upper part of this seam consists of thin interbedded siltstone and argillaceous layers (weathered acid volcanic ash) and thin layers of coal. Influx of the clastic material favoured the displacement of plants which were growing along the margins of this swamp. In addition to dispersed cuticles of Araucariodendron, the remains of the bennettite Nilssoniopteris rithidorachis and conifer Tombarrisia florinii Krassil. were discovered. The taxonomic composition of the palynospectrum from the upper part of the lower thick coal seam also shows changes, due to the reducing significance of the Gleicheniaceae, increasing significance of Leiotriletes, the ap- 
pearance of bisaccate pollen, which in the higher strata [of this section] becomes a ubiquitous participant in the spectra, albeit in small quantities.

The upper productive coal seam (1-2 m thick) is partially composed of rhabdopissite. Identified cuticles mainly belong to the Miroviaceae; the representatives of Cheirolepidiaceae are rare.

The palynospectrum from the mudstone at the bottom of the upper coal seam is characterized by increased taxonomic diversity (the appearance of angiosperms is particularly remarkable) and a change of the dominant taxa: Ginkgocycadophytus begins to play a dominant role, and there is a sharp reduction in the significance of the Gleicheniaceae.

The palynospectrum from the upper coal seam is characterized by low taxonomic diversity, dominance by ferns (Gleicheniaceae, Cyatheaceae, Leiotriletes - more than 60\%). Ginkgocycadophytus frequency is rather high (up $16.7 \%$ ); whereas pollen of angiosperms is extremely rare.

In the upper part of section, there is an alternation of fine-grained sandstone, silty mudstones and thin coal layers. The last are composed of remains of Miroviaceae, but with increasingly diverse bennettites Anomozamites arcticus Vassil., Nilssoniopteris rbitidorachis, N. prynadae Samyl., and Nilssoniopteris sp. The dispersed cuticles of allegedly angiosperms are extremely rare.

The palynospectrum is dominated by Gleicheniaceae; the importance of the other ferns is very limited. The taxonomic diversity on the palynospectrum is quite high, including by angiosperms.

\section{Konstantinovskoe Coalfield (Poltavka mine)}

The section at the Poltavka coal mine is geologically similar to the previous one. At the base of the sequence a member with very well-developed coals occurs, including rhabdopissite seams. It is overlain by alternating sandstones, siltstones and thin coal seams.

Coals consists of the following plants: bennettitalean Nilssoniopteris rbitidorachis, taxodialean Athrotaxites orientalis Deng and Chen, Miroviaceae (Mirovia sp.).

\section{CONCLUSION}

Professor Krassilov so deeply and thoroughly has studied the Early Cretaceous plants of the Razdolnaya River Basin that those who follow can only add some finishing touches to the image of this fossil flora. But he conducted his research in the 1960 s, and some problems remain unsolved. For instance, it is necessary to study the cuticles of leaves using scanning and transmission electron microscopy. It is still unknown, what is role was played by plants in the formation of coal, and it is necessary to identify their floral composition, to reveal the structure of the swamp plant communities. Further, the Razdolnaya River Basin is the place of origin of unique resinous coals. Bugdaeva and Markevich revealed that they are composed mainly of Miroviaceae, but the following question remains - how were rhabdopissites formed?

Based on our research we can conclude that in the Aptian the main components of the swamp plant communities were conifers Miroviaceae, Araucariaceae, taxodialeans (Athrota- xites orientalis), ginkgoaleans (Pseudotorellia krassilovii), bennettites, as well as gleicheniaceous and cyatheaceous ferns. These plants supplied the material for the accumulation of rhabdopissite and rhabdopissite-humic coals in the Razdolnaya River Basin of Southern Primorye.

\section{ACKNOWLEDGEM ENTS}

We, the authors, express our appreciation to Prof. V.A. Krassilov for the happiness brought by his appearance in our lives, for his advices, help, and kindness. We are grateful to Prof. Sun Ge and Dr. W. Wimbledon for corrections in this paper.

\section{LITERAT URE CITED}

Ammosov, I.I. et al. (eds.) 1973. Geology of Coal and Oil Shale Deposits in the USSR. Vol. 9. Book 1. Nedra, Moscow, 691 pp. (in Russian). [Геология месторождений угля и горючих сланцев СССР / реА. Аммосов И.И. и ар. Том 9. Москва: Нелра, 1973. 691 с.].

Bolkhovitina, N.A., I.Z. Kotova 1963. The spore-pollen assemblages of the coal-bearing deposits of Suifun Basin on Far East. Izvestiya Akademii Nauk. Ser. Geol. 1: 77-92 (in Russian). [Болховитина Н.А., Котова И.З. 1963. Спорово-пыльцевые комплексы угленосной толщи Суйфунского бассейна на Аацьнем Востоке // Изв. АН СССР, сер. геол. № 1. С. 77-92].

Bugdaeva, E.V. 1995. Pseudotorellia from the Lower Cretaceous coal-bearing deposits of Eastern Transbaikalia. $\mathrm{Pa}$ leontological Journal 29(1A):182-184.

Bugdaeva, E.V. 1999. The History of the genus Psendotorellia Florin (Pseudotorelliaceae, Ginkgoales). Paleontological Journal 33(5):566-576.

Bugdaeva, E.V. 2010. New Species of Sphenobaiera Florin (Ginkgoales) from the Lower Cretaceous of Transbaikalia. Paleontological Journal 44(10): 1240-1251.

Bugdaeva, E.V. \& V. S. Markevich 2009. The coal-forming plants of Rhabdopissites in the Lipovtsy coalfield (Lower Cretaceous of Southern Primorye). Paleontological Journal 43(10):1217-1229.

Gordenko, N.V. 2004. On the taxonomy of the genus Tritaenia Mägdefrau et Rudolf (Coniferales), with descriptions of new species. Paleontological Journal 38(6):687-697.

Gordenko, N.V. 2007. A new species of the conifer genus Oswaldheeria with well-preserved leaf anatomical elements from the Bathonian of the Kursk Region. Paleontological Journal 41(3): 319-326.

Kirichkova, A.I. 1985. Phytostratigraphy and Flora of the Jurassic and Lower Cretaceous Deposits of the Lena River Basin. Nedra, Leningrad, 222 pp. (in Russian). [Киричкова А.И. 1985. Фитостратиграфия и флора юрских и нижнемеловых отложений Аенского бассейна. АенинграА: НеАра. 222 с.].

Krassilov, V.A. 1964a. A new gymnosperms from the Lower Cretaceous of Prymorye region. Paleontologicheskii Zhurnal 1: 114-119 (in Russian). [Красилов B.A. 1964. Новые голосеменные из нижнего мела Приморья // Палеонтологический журнац. № 1. С. 114-119].

Krassilov, V.A. 1964b. About genus Nathorstia (ferns). Paleontologicheskii Zhurnal 2: 115-120 (in Russian). [Красимов B.A. 1964. О роде Nathorstia (папоротники) // Памеонтологический журнац. № 2. С. 115-120].

Krassilov, V.A. 1965a. Stratigraphy and fossil flora of Lower Cretaceous deposits of Suifun Basin. Geologiya i Geofizika 1:124-131 (in Russian). [Красилов B.A. 1965. Стратиграфия и ископаемая флора нижнемеловых отложений Суйфунского каменноугольного бассейна // 
Геология и геофизика. № 1. С. 124-131].

Krassilov, V.A. 1965b. Araucariaceae from the Lower Cretaceous of Primorye region. Paleontologicheskii Zhurnal2:109_ 117 (in Russian). [Красилов B.А. 1965. Араукариевые из нижнего мела Приморья // Палеонтологический журнац. № 2. C. 109-117].

Krassilov, V.A. 1965c. New conifers from the Lower Cretaceous of Primorye region. Botanicheskii Zhurnal 50(10): 1450-1455 (in Russian). [Красилов B.А. 1965. Новые хвойные из нижнемеловых отложений Приморья // Ботанический журнал. Т. 50, № 10. С. 1450-1455].

Krassilov, V.A. 1965d. New finds of angiosperms in the Lower Cretaceous of Primorye and their bearing on stratigraphy. Doklady Akademii Nauk SSSR 160(6): 1381-1384 (in Russian). [Красилов В.А. 1965. Новые находки покрытосеменных растений в нижнемеловых отложениях Приморья и их значение Аля стратиграфии // Аоклады АН СССР. Т. 160, № 6. С. 1381-1384].

Krassilov, V.A. 1967. Early Cretaceous Flora of Southern Primorye and Its Stratigraphic Significance. Nauka, Moskva, 364 pp. (in Russian). [Красилов В.А. 1967. Раннемеловая флора Южного Приморья и ее значение Аля стратиграфии. Москва: Наука. 364 с.].

Krassilov, V.A. 1972. Mesozoic Flora of the Bureya River (Ginkgoales and Czekanowskiales). Nauka, Moscow, 150 pp. (in Russian). [Красилов В.А. 1972. Мезозойская фмора реки Буреи (Ginkgoales и Czekanowskiales). Москва: Наука, 152 с.].

Kryshtofovich, A.N. 1910. Jurassic plants of the Ussuryisk Krai. Trudy Geologicheskogo Komiteta 56:1-23 (in Russian). [Криштофович, А. 1910. Юрские растения Уссурийского края / / Труды Геол. К-та. Новая серия. Вып. 56. C. 1-23].

Kryshtofovich, A.N. 1916. Materials on the Jurassic flora of the Ussuryisk Krai. Trudy Geologo-Mineralogicheskogo Muzeya Imperatorskoi Akademii Nauk 2(4):81-140 (in Russian). [Криштофович А.Н. 1916. Материалы к познанию юрской флоры Уссурийского края // Труды геол. и минерал музея АН СССР. Т. 2, вып. 4. С. 81-140].

Kryshtofovich, A.N. 1919. On the flower of Williamsonia sp., found near Vladivostok, and some other plants from the Maritime Province of the Asiatic Russia. Journal of the Geological Society of Tokyo 26(30):1-5.

Kryshtofovich, A.N. 1921. Discovery of equivalents of the Lower Jurassic Tonkin beds in the Ussuriysk Krai. Materialy po Geologii i Poleznym Iskopaemym Dal'nego Vostoka 22: 1-30 (in Russian). [Криштофович А.Н. 1921. Открытие эквивалентов нижнеюрских пластов Тонкина в Уссурийском крае // Материалы по геологии и полезным ископаемым Аальнего Востока. Вып. 22. С. 1-30.].

Kryshtofovich, A.N. 1923. Pleuromeia sternbergï Münst. and Hausmannia ussuriensis n. sp. from the Mesozoic deposits of the South Ussuryisk Krai. Irvestiva Rossiiskoi Akademii Nauk 17:291-300 (in Russian). ККриштофович A.H. Pleuromeia Sternbergii Münst. и Hausmannia ussuriensis n. sp. из мезозойских отложений Южно-Уссурийского края", Известія Россійской Академіи Наукъ. VI серія, вып. 17. C. 291-300].

Kryshtofovich, A.N. 1928. The Liportsy Coal Mines in the Ussuri River Region. Materialy Geologicheskogo Komiteta po Prikladnoi i Economicheskoi Geologii 81. Geologicheskii Komitet, Leningrad (in Russian). [Криштофович A.H. 1928. Аиповецкие каменноугольные копи в Уссурийском крае // Мат-лы по общей и прикладной геол. Аенинград: Геол. ком. Вып. 81. С. 1-36].

Kryshtofovich, A.N. 1929. Discovery of oldest dicots (Angiosperms) and equivalents of the Potomac Beds in the
Suchan area, Ussuriisk Krai. Izvestia Geologicheskogo Komiteta 48(9):113-124 (in Russian). [Криштофович А.Н. 1929. Открытие Аревнейших Авудольных покрытосеменных и эквивацентов потомакских слоев на Сучане в Уссурийском крае // Изв. Геол. ком. Т. 48, №9. С. 113-124].

Manum, S.B., J.H.A. Van Konijnenburg-Van Cittert \& V. Wilde 2000. Tritaenia Mägdefrau et Rudolf, Mesozoic 'Sciadopitys-Like' Leaves in Mass Accumulation. Review of Palaeobotany and Palynology 109:255-269.

Markevich, V.S. 1994. Palynological zonation of the continental Cretaceous and lower Tertiary of eastern Russia. Cretaceous Research 15:165-177.

Markevich, V.S. 1995. Cretaceous Palynoflora of the Northern East Asia. Dal'nauka, Vladivostok, 200 pp. (in Russian). [Маркевич В.С. 1995. Меловая палинофлора севера Восточной Азии. ВАадивосток: Аальнаука. 200 с.].

Nosova, N.V. 2001. First finds of the genus Oswaldheeria (Miroviaceae, Pinopsida) in the Lower Cretaceous of Northern Asia. Paleontologicheskii Zhurnal 4: 106-109 (in Russian). [Носова Н.B. 2001. Первые находки рода Oswaldheeria (Miroviaceae, Pinopsida) в нижнемеловых отложениях Северной Азии // Палеонтологический журнац. № 4. С. 106-109].

Prynada, V.D. 1937. The Mesozoic Flora of the South Ussury Region. Mesozoic Cycadophytes of the Ussury Region. Dal'nevostochnii Gidrogeologicheskii Trest, Khabarovsk, 252 pp. (in Russian). ППринада В.А. 1937. Мезозойская фмора Южно-Уссурийского края. Цикадофиты уссурийского мезозоя. Хабаровск: АВГГГТ. 252 с.].

Prynada, V.D. 1939. The Mesozoic flora of the South Ussury Region. Mesozoic conifers of the Ussury Region. VSEGEI, Leningrad, 102 pp. (in Russian). [Принала В.А. 1939. Мезозойская фиора Южно-Уссурийского края. Хвойные уссурийского мезозоя. АенинграА: Геол. фонды ВСЕГЕИ. 102 с.].

Prynada, V.D. 1941. About Results of Study of the Mesozoic Flora of the South Ussury Region. Dal'nevostochnii Gidrogeologicheskii Trest, Khabarovsk, 58 pp. (in Russian). [ПринаАа В.А. 1941. О результатах исследования мезозойской флоры Южно-Уссурийского края. Хабаровск: Аальневост. гиАро-геол. трест. 58 с.].

Samylina, V.A. 1961. A new data on the Lower Cretaceous flora of Southern Primorye. Botanicheskii Zhurnal 46(5): 634-645 (in Russian). [Самылина B.А. 1961. Новые Аанные о нижнемемовой флоре Южного Приморья // Ботанический журнал. Т.46, № 5. С. 634-645].

Sharudo, I.I. 1972. History of the Late Mesozoic Coal Formation in the Far East. Nauka, Novosibirsk, 239 pp. (in Russian). [Шарудо ИА. 1972. История позднемезозойского угленакопления на территории Аальнего Востока. Новосибирск: Наука. 239 с.].

Shtempel, B.M. 1924. Geological Structure of the Southwestern Part of the Muravyov-Amurskii Peninsula. Khabarovsk (in Russian). [Штемпель Б.М. 1924. Геологическое строение юго-западной части п-ова Муравьева-Амурского. Хабаровск. 88 с.].

Shtempel, B.M. 1926. The Uglovsky District. In: Report on the Geological Studies during Autumn, 1924. Dal'nrvostochnii gosudarstvennii Universitet, Vladivostok (in Russian). Штемпель Б.М. 1926. Угловский район. Отчет о геомогическом исследовании осенью 1924 г. // Матер. по геол. и пол. ископ. АаАьн. Востока].

Shtempel, B.M. 1960. Cretaceous phytostratigraphy of Southern Primorye. Trudy Laboratorii Geologii Uglya AN SSSR 10:167193 (in Russian). [Штемпель Б.Н. 1960. Фитостратиграфия меловой системы Южного Приморья. //Тр. мабор. угля АН СССР, вып. 10. М.-А.: Наука. С. 167-193.]. 
Shugaevskaya, O.V. 1962. The spore-pollen assemblages of the Upper Jurassic and Lower Cretaceous of the South of Far East., pp. 19-21. DVNC AN SSSR, Vladivostok (in Russian). [Шyгаевская О.В. 1962. Спорово-пыльцевые комплексы верхнеюрских и нижнемеловых отложений юга Аальнего Востока. ВАадивосток: АВНЦ АН СССР. С. 19-21.].

Shugaevskaya, O.V. 1966. On nomenclature and distribution of spores of Schizaeaceae and form-genera Contignisporites, Pilosisporites, Cicatricosisporites in the Lower Cretaceous deposits of the South of Far East. In: Importance of palynological analysis for stratigraphy and paleofloristics, pp. 112-120. Nauka, Moscow (in Russian). Шугаевская О.В. 1962. О номенклатуре и распространении спор Schizaeaceae и формальных родов Contignisporites, Pilosisporites, Cicatricosisporites в нижнемеловых отложениях юга Аальнего Востока // Значение палинологического анализа Аля стратиграфии и палеофмористики. Москва: Наука. С. 112-120].

Shugaevskaya, O.V. 1977. The spores and pollen of the Early Cretaceous of the South of Far East and their stratigraphic significance. VINITI, Moscow, 22.03.77, no. 1317. 207 pp. (in Russian). [Шугаевская О.В. 1977. Споры и пыльца раннего мела юга Аальнего Востока и их стратиграфическое значение. М.: ВИНИТИ. 207 с.].

Vakhrameev, V.A. 1959. The Lower Cretaceous plants near Khanka Lake. Botanicheskii Zhurnal 44(7): 997-1000 (in Russian). [Вахрамеев В.А. 1959. Нижнемеловые растения с оз. Ханки (Приморье) / / Ботанический журнац. T. 44, №7. C. 997-1000].

Verbitskaya, Z.I., O.A. Dzens-Litovskaya, \& B.M. Shtempel 1965. Cretaceous vegetation and coals of the Primorsky coal-bearing basin. Nauka, Moskva, Leningrad, 118 pp. (in Russian). [Вербицкая 3.И, Азен-Аитовская О.А., Штемпель Б.М. 1965. Меловая растительность и угли Приморского угленосного бассейна. Москва, АенинграА: Наука. 118 с.].

Volynets, E.B. 2005. The Aptian-Cenomanian flora of Primorye. Part 1: Floral assemblages. Stratigraphy and Geological Correlation 13(6):613-631.

Volynets, E.B. 2006. The Aptian-Cenomanian flora of Primorye. Part 2: Correlation of floral assemblages. Stratigraphy and Geological Correlation 14(2):200-210. 